Meta

Journal des traducteurs

Translators' Journal

\title{
"Man" and Sexual Discrimination
}

\section{Mary Coppin}

Volume 26, numéro 2, juin 1981

URI : https://id.erudit.org/iderudit/002369ar

DOI : https://doi.org/10.7202/002369ar

Aller au sommaire du numéro

Éditeur(s)

Les Presses de l'Université de Montréal

ISSN

0026-0452 (imprimé)

1492-1421 (numérique)

Découvrir la revue

Citer cet article

Coppin, M. (1981). "Man" and Sexual Discrimination. Meta, 26(2), 168-172.

https://doi.org/10.7202/002369ar

Ce document est protégé par la loi sur le droit d'auteur. L'utilisation des services d'Érudit (y compris la reproduction) est assujettie à sa politique d'utilisation que vous pouvez consulter en ligne.

https://apropos.erudit.org/fr/usagers/politique-dutilisation/
Cet article est diffusé et préservé par Érudit.

Érudit est un consortium interuniversitaire sans but lucratif composé de l'Université de Montréal, l'Université Laval et l'Université du Québec à Montréal. Il a pour mission la promotion et la valorisation de la recherche. https://www.erudit.org/fr/ 


\section{"MAN" AND SEXUAL DISCRIMINATION}

The Canadian Human Rights Act, passed July 14, 1977 , forbids discrimination on the basis of sex, and the provinces have similar legislation. The ramifications of this ban are far-reaching, but the purpose of this review is to examine its ricochet effect on the common English usage of "man" in occupational job titles in the work place, in advertising and, in a limited way, on the ideology of the language.

\section{THE WORK PLACE}

"Man" forms part of the title of a good many occupations which are open to both sexes. In the telecommunications field, for example, there are titles such as central officeman, repairman, lineman, cable repairman, combinationman, installer-repairman, foreman, etc. On the surface it might seem quite a simple matter to "de-sex" such titles by replacing "man" as appropriate, with agent, worker, person, operator, attendant, technician, controller, servicer, representative, or with a completely new title with no sex connotation. But it is not that easy.

The first requirement is to examine the job duties, so that any alternative chosen will adequately describe the occupation. A suffix which is suitable in one industry might be quite unacceptable in another. Some of the other considerations which enter into the selection of titles are as follows: "Agent" is a title used by some union organizers and might therefore be inappropriate for use within a bargaining unit. "Worker" is felt by some to lack prestige. As a case in point, "janitor" of an apartment building has been, for the most part, displaced in our day by "superintendent" which imparts more status. Some titles, such as foreman, embody long held and cherished concepts. Others become almost

1. Canadian Human Rights Act, CS 1977, Chap. 33. 
tongue twisters with the addition of a longer suffix, so that from a terminological point of view their usability would be affected.

It must be kept in mind, also, that changes in titles for bargainable employees cannot be made unilaterally and are subject to negotiation. In addition, the Federal Interpretation Act, which provides guidance for terminology in legal documents under Federal jurisdiction, states: "Words importing male persons include female persons and corporations" ${ }^{2}$. The Quebec Interpretation Act supports this view: "Le genre masculin comprend les deux sexes à moins que le contexte n'indique le contraire" 3 . Other provincial legislation follows suit. Although it is not common, some collective agreements have a "sex" clause of their own, which indicates that the use of the masculine or feminine gender is to be construed as including both male and female employees and not as specific sex designations ${ }^{4}$. This means that titles covered by collective agreements may retain a "man" suffix and remain within the law. While this may appear to afford some opportunity to maintain the status quo, it also permits employees to have a say, through their union representatives, in designations used to describe their jobs. This latter factor can have a marked effect on the acceptance of new or changed titles by the employees concerned. It is evident, therefore, that the de-sexing of titles involves much more than the mere substitution of a suffix, although one could easily be led astray by employment advertizing.

\section{ADVERTIZING}

The Human Rights Act forbids any advertizing for jobs available which appears to exclude certain groups or individuals because of a prohibited ground of discrimination ${ }^{5}$. In employment advertizing the attempt to meet this requirement produces some ludicrous results. For example, in the Montreal Gazette we find firms on the lookout for a maintenance handy person, an auto bodyperson, a purchasing person, a doorperson and an offset pressperson ${ }^{6}$. The Toronto Globe and Mail includes advertizements for draftspersons, production foreperson, repair person ${ }^{7}$.

Incredible as it may seem a "person Friday" is a very common job, sometimes specialized as a book-keeper person Friday or a person Fridaytypist $^{8}$. Robinson Crusoe would turn over in his grave! Incidentally, Webster

2. The Interpretation Act, RSC 1967-68, Chap. 1-23, Sec. 26(6).

3. La Loi d'interprétation, QSR 1964, c. 1, a. 63.

4. Collective Agreement between Canadian Telephone Employees' Association and Bell Canada, covering Clerical and Associated Employees, Montreal, Bell Canada, 1979, Article 2.

5. Canadian Human Rights Act, op. cit., Chap. 33, Sec. 8.

6. The Gazette, Montreal, Southam Incorporated, Daily, January 16, 1980, April 2, 1980.

7. The Globe and Mail, Toronto, A Roy Megarry (Richard J. Doyle Editor-in-Chief), Daily, March 25, 1980.

8. The Gazette, op. cit., January 16, 1980. The Financial Post, Toronto, MacLean-Hunter Business Publishing Company, Weekly, March 29, 1980. 
describes a "man Friday" as a "right-hand man" 9 - so it is not inconceivable that employers will soon be looking for a "right-hand person"!

Some advertizers meet the problem in a different way - "designers and draughtsmen (male or female)" or "maintenance foreman/woman", but these are, at best, transitional solutions ${ }^{10}$.

"Person" appears to be the suffix most frequently used to replace man in spite of the fact that it produces titles which are awkward, and in some cases an affront to the English language.

It is paramount to remember, in any case, that designations are just the tip of the iceberg. The thrust of the Human Rights Act, as it affects the work place, is to eliminate discrimination in employment and in opportunities for advancement. Titles are only one step, albeit an important one, towards compliance with that legislation.

The problem goes deeper than the mere substitution of "person" or some other alternative to indicate sex. There are still the pronouns he, she, himself, herself. Advertizing copy could become very awkward indeed with a repetition and "he or she" or "himself (herself)", but with a little ingenuity in composition the sexual reference can be avoided or reduced to a minimum. It may require frequent repetition of the subject, but it is feasible. Much advertizing copy is now personalized and speaks directly to a prospective candidate as "you". This is a flattering approach, very much in the English idiom and the next best thing to being called by name. Other terms used to de-sex the advertizing are: the manager, the applicant, the individual, the incumbent, the candidate, the position and the executive.

Another example of an intelligent endeavour to de-sex advertizing copy is the treatment of "businessman" and the advertizer's approach to women in business. The advent of women into the business world in such numbers and particularly into the higher echelons of management is a comparatively recent phenomenon. It is not against the law to seek only the businessman's trade, but it is certainly shortsighted. A review of Time Magazine airline and hotel advertizing over the past year revealed that although the reference to the "businessman" has by no means disappeared, most advertizers have discovered a variety of terms to get their idea across and avoid the sexual connotation ${ }^{11}$. For example, they appeal to the business traveller, business people, the business executive, or extol the advantages of business class travel, business travel or simply, business, with the travel implied. Here again of course, the advertizements are often personalized. It was, however, interesting to note, that although most advertizing copy scrupulously avoids any sexual reference, many of the illustrations feature only men! Lip service? Custom dies hard!

In the economic field too, businessman, in the generic sense, appears quite often. A recent Financial Post Special Report devoted to small business made

9. Webster's Third New International Dictionary, op cit., under "man Friday".

10. The Gazette, op. cit., April 2, 1980.

11. Time, Richmond Hill, Ont., Time Canada Ltd., Weekly. 
frequent reference to "the small businessman" or men ${ }^{12}$, although in most instances, an alternative such as "small business" would have served just as well.

There will always be situations which require the use of businessman or businesswoman, but it is almost inevitable that certain terms will fall victim to the effects of social change. "Businessmen's lunch" for example, to describe a noon meal with a simplified menu at a fixed price ${ }^{13}$ is obsolescent, if not already outmoded, except within the confines of a man's club (of which few remain). Such lunches were always served to anyone who ordered them, but in today's climate, to feature a "businessmen's lunch" is, at the very least, poor merchandizing, particularly when it is so easy to make the term acceptable. An unimaginative effort may produce an alternative heard recently on a local radio station - "table d'hôte - business persons". On the other hand, a Financial Post column featuring this type of lunch is entitled simply "The Business Lunch" ${ }^{14}$. That would appear to fit the bill of fare.

It should be mentioned that the terms "spokesperson" and "chairperson" have made some headway, although they generally refer to the female gender and have not displaced chairman and spokesman in the written and spoken word. This points up the fact that usage lends credence, or at least dulls the sensibilities.

\section{IDEOLOGY}

Quite apart from other considerations, the "man" problem has ideological and socioeconomic implications. To pursue it to absurdity would rob the English language of some of its ideological heritage. We could no longer canvass the "man in the street" nor muse on the "man in the moon", nor reach a conclusion "to a man". The business world would be robbed of manmade, manhours, manpower - to mention but a few, and of inspirational advertizing such as "The continually expanding horizons of man demand constantly advancing technology and systems" ${ }^{15}$. The inescapable fact is that "man" according to Webster, is "a member of the human race - a human being" 16 and therefore does not necessarily imply a sexual connotation.

\section{CONCLUSION}

That does not offer much solace to anyone beset with an assignment to de-sex titles. But there is an urgent need to tread softly! The current "person" trend would lead one inevitably to paraphrase even the Webster definition and

12. The Financial Post, op. cit., April 5, 1980, Special Report, 3rd Section.

13. C'est-à-dire, Fiches Radio-Canada, 165, "businessmen's lunch".

14. The Financial Post, op. cit., April 5, 1980, p. 34.

15. Time, op. cit., Nov. 12, 1979, "Man in Control", p. 56.

16. Webster's Third New International Dictionary, Springfield, Mass., G \& C Merrian Company, 1971 , sv. 
say that "man is a member of the huperson race - a huperson being!" But there are other suffixes and other titles which will avoid discrimination and satisfy the user. There are also a variety of strategems to remove any sexual connotation from advertizing copy and these could be employed, with equal effect, in instructions, practices or other written material. The problem is not easy and it is also evolutionary, but the obstacles can be overcome with intelligence and flexibility. We should avoid at all costs a too purist attitude which might result for instance, as recently reported on local radio, in issuing a bulletin on maternity benefits which referred meticulously to the "pregnant person". No discrimination there!

\section{SUMMARY OF DE-SEXING ALTERNATIVES}

FOR

\begin{tabular}{|c|c|c|c|c|}
\hline $\operatorname{man}$ & $\begin{array}{l}\text { he, she } \\
\text { himself, herself }\end{array}$ & $\begin{array}{l}\text { businessman } \\
\text { (travel) }\end{array}$ & $\begin{array}{c}\text { small } \\
\text { businessman }\end{array}$ & $\begin{array}{c}\text { businessmen's } \\
\text { lunch }\end{array}$ \\
\hline $\begin{array}{l}\text { agent } \\
\text { attendant } \\
\text { controller } \\
\text { operator } \\
\text { person } \\
\text { representative } \\
\text { servicer } \\
\text { technician } \\
\text { worker }\end{array}$ & $\begin{array}{l}\text { the applicant } \\
\text { the candidate } \\
\text { the executive } \\
\text { the incumbent } \\
\text { the individual } \\
\text { the manager } \\
\text { the position } \\
\text { you } \\
\text { repetition of subject }\end{array}$ & $\begin{array}{l}\text { business } \\
\text { business class travel } \\
\text { business executive } \\
\text { business people } \\
\text { business travel } \\
\text { business traveller } \\
\text { you }\end{array}$ & small business & business lunch \\
\hline
\end{tabular}

MARY COPPIN 